\title{
Peningkatan HOTs dan Reduksi Miskonsepsi Pembelajaran Fisika dengan Mengkomparasi Inquiry Learning dan Problem Solving: Studi Meta-Analisis
}

\author{
Aziz Kurniawan \\ Institut Agama Islam Negeri Purwokerto \\ Jl. Ahmad Yani No 40 Purwokerto \\ E-mail: azizkurniawan0705@gmail.com
}

\begin{abstract}
Abstrak
Peran guru dalam proses pembelajaran memiliki peran sangat penting terhadap keberhasilan pada proses pembelajaran. Namun, kenyataan dilapangan guru belum bisa memberikan pengalaman yang bermakna pada proses pembelajaran sehingga mengakibatkan rendahnya keterampilan HOTs dan tingginya miskonsepsi terutama pada mata pelajaran fisika yang cenderung siswa kaya akan teori saja. Penelitian ini bertujuan untuk mengetahui besar effect size dengan mengkomparasi Inquiry Learning dengan Problem Solving untuk meningkatkan HOTs dan mereduksi miskonsepsi fisika. Dalam penelitian ini peneliti mengumpulkan artikel sebanyak 21 yang terdiri dari 10 Inquiry Learning dan 11 Problem Solving. Hasil pada penelitian ini yaitu $F_{\text {hitung }}>$ $F_{\text {tabel }}$ yaitu 4,355 > 3,55, dan nilai probabilita 0,029 <0,05 yang berarti komparasi Inquiry Learning dengan Problem Solving mampu untuk meningkatkan HOTs dan mereduksi miskonsepsi
\end{abstract}

Kata kunci: HOTs, Reduksi Miskonsepsi, Inquiry Learning, Problem Solving

\begin{abstract}
The role of teachers in the learning process has a very important role to play in producing the learning process. However, the reality in the field of teachers has not been able to provide the existing experience in the learning process so it can cause them to engage in HOTs and there are still misconceptions, especially physics subjects where students are just the theory. To learn about research by comparing Inquiry Learning with Problem Solving in order to increase HOTs and reduce physics misconceptions. This study reported 21 articles that included 10 Inquiry Studies and 11 Problem Solving. The result of this research is that Fhitung > Ftabel is 4,355> 3.55, and a probability value of $0.029<0.05$ which means a comparison of Learning about Problem Solving that can result in HOTs and misconceptions.
\end{abstract}

Keywords: HOTs, Misconception Reduction, Inquiry Learning, Problem Solving

\section{PENDAHULUAN}

Manusia merupakah makhluk istimewa dan memiliki kelebihan yang berbeda dengan makhluk lainnya yang diciptakan oleh Allah SWT. Salah satunya yaitu berakal sehingga manusia bisa menggunakannya untuk berpikir. Dengan dibekali adanya akal manusia dapat berpikir sehingga bisa mendapatkan ilmu yang mana bisa digunakan untuk bekal dunia dan akhirat. IImu bagaikan lentera yang menyinari pada ruangan gelap, dengan adanya ilmu manusia bisa membedakan mana yang baik dan mana yang buruk. Setelah memiliki ilmu hendaknya manusia untuk mengamalkan hal tersebut melalui kegiatan belajar mengajar. Pane \& Darwis (2017) menjelaskan kegiatan yang dilakukan manusia dalam mendapatkan dan mentransfer ilmu atau sering kita sebut sebagai kegiatan belajar dan mengajar atau kegiatan edukatif yang merupakan kegiatan yang tidak bisa dipisahkan satu dengan yang lainya. Pada kegiatan belajar mengajar tentunya memiliki tujuan tertentu sesuai yang dirancang oleh pendidik agar pembelajaran yang dilakukan berhasil dan siswa dapat 
memahami dari materi yang sudah diberikan oleh pendidik.

Menurut Sutikno (2021) dalam bukunya menyebutkan bahwa pembelajaran yang dikatakan baik merupakan pembelajaran yang mampu mengkondisikan siswa dalam belajar untuk beraktivitas secara aktif dan memberikan ruang kepada siswa dalam menemukan pengetahuannya sendiri sehingga mampu mengembangkan potensi yang ada pada diri siswa secara maksimal. Selain mengarahkan pada pembelajaran yang aktif bagi siswa tentunya pembelajaran yang bermakna akan memberikan pengalaman berharga kepada siswa. Dengan pembelajaran yang bermakna pengetahuan yang didapat oleh siswa tidak akan mudah dilupakan hal tersebut sejalan dengan pendapat (Setyowati \& Firmansyah, 2018; Setyowati \& Mawardi, 2018; Muamanah \& Suyadi, 2020).

Terciptanya pembelajaran yang bermakna merupakan peran penting yang harus dimiliki oleh pendidik dalam merancang suatu program pembelajaran yang dikemas dalam RPP bagi guru atau RPS bagi dosen. Akan tetapi harapan untuk pembelajaran yang bermakna tidak berbanding dengan keadaan nyata pada lapangan, hal ini diperkuat dengan pernyataan beberapa peneliti terdahulu (Halim, 2018; Aryani, 2019; Baharuddin, 2020; \& Sholeh et al, 2021).

Karena pembelajaran yang sering terjadi kurang memberikan pengalaman bermakna untuk siswa mengakibatkan hasil belajar yang diperoleh kurang memuaskan hal tersebut tentunya mempengaruhi High Order Thinking Skill (HOTs) maupun tingginya miskonsepsi yang diterima siswa terlebih pada mata pelajaran fisika. Mata pelajaran fisika merupakan mata pelajaran selain menekankan pada kontekstual namun juga pada praktek yang dilakukan agar mampu memberikan kesan bermakna kepada siswa, sehingga mampu meningkatkan keterampilanketerampilan seperti yang diharapkan. Berdasarkan hasil PISA yang telah dilakukan, Indonesia masih menempati posisi terendah dalam kurun waktu 10 hingga 15 tahun terakhir dari tahun 2000-2018. Berikut grafik skor PISA yang diperoleh Indonesia.

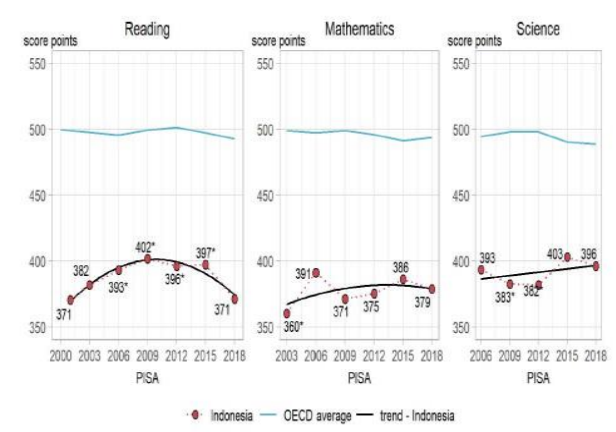

Gambar 1. Grafik Hasil PISA Indonesia

Berdasarkan uraian diatas peneliti memandang untuk mengatasi permasalahan tersebut perlu solusi yang tepat yaitu dengan menerapkan model pembelajaran yang inovatif serta memusat pada kegiatan student center. Salah satu model yang inovatif dan berpusat pada siswa yaitu Inquiry Learning dan Problem Solving.

Inquiry Learning merupakan pembelajaran yang berpusat pada siswa dengan membimbing siswa untuk melakukan penyelidikan suatu permasalahan yang dihadapi yang kemudian siswa diminta membuat solusi untuk mengatasi permasalahan yang dihadapi (Nurfitria \& Hertanti, 2020). Putri \& Aznam (2020) menambahkan pernyataan selain untuk membuat solusi Inquiry Learning memberikan kesempatan kepada peserta didik untuk mengemukakan pendapatnya sehingga siswa menerima masukan pengetahuan selain dari guru juga memperoleh informasi tambahan dari teman sejawat. Dalam pelaksanaannya peran pendidik dalam melaksanakan sebagai fasilitator dan pengatur jalannya proses penyelidikan dari suatu masalah yang dihadapi siswa berjalan lancar, sistematis dan terarah (Jundu et al, 2020).

Problem Solving merupakan model pembelajaran yang dimana dalam pembelajaran siswa dapat memecahkan masalah yang dihadapi dan dapat mengevaluasi hasil dari pemecahan masalah tersebut (Handayani et al; 2018). Dalam riset yang telah dilakukan oleh Indriyanti et al, (2020) menyebutkan dalam pembelajaran yang mengunakan problem solving memberikan arti penting bagi siswa karena dalam prosesnya siswa memperoleh informasi pengetahuan melalui kegiatan pemecahan masalahnya sendiri dengan cara mereka sendiri. 
Sependapat dengan pernyataan tersebut (Nurhamidah et al, 2019) menambahkan bukanlah hasil yang menjadi patokan dalam keberhasilan pembelajaran dengan menerapkan problem solving melainkan kepada proses yang telah dilalui sehingga memperoleh solusi atas permasalahan yang dihadapi.

Peneliti memandang kedua model tersebut bisa dijadikan alternatif untuk mengatasi permasalahan yang dihadapi yaitu meningkatkan HOTs serta mereduksi miskonsepsi yang sering terjadi pada pembelajaran Fisika. Berdasarkan permasalahan tersebut tujuan dilakukan penelitian ini yaitu melihat besar effect size dari mengkomparasi model Inquiry dan Problem solving untuk meningkatkan HOTs dan mereduksi miskonsepsi pada pembelajaran fisika.

\section{METODE/EKSPERIMEN}

Penelitian yang diterapkan pada proses penelitian ini yaitu penelitian meta-analisis dimana maksud dari penelitian meta-analisis yaitu penelitian yang menggunakan data dari beberapa kumpulan artikel-artikel pada penelitian yang terdahulu yang sesuai dengan scope pada penelitian yang dilakukan oleh peneliti untuk dianalisis (Anugraheni, 2018). Artikel-artikel yang dikumpulkan merupakan hasil dari pencarian dengan menggunakan Search Engine google scholar dengan kata kunci Inquiry Learning", "Problem Solving", "HOTs"dan "reduksi miskonsepsi".

Berdasarkan hasil pencarian pada Search Engine di google scholar ditemukan 25 artikel dengan rentang waktu dari 2015-2021 yang memiliki scope yang sesuai dengan kata kunci "Inquiry Learning", "Problem Solving", "HOTs" dan "reduksi miskonsepsi" dimana artikel-artikel yang telah ditemukan merupakan jenis penelitian eksperimen yang telah dilakukan oleh peneliti terdahulu yang berarti penelitian tersebut memiliki hasil berupa nilai pretest dan posttest. Langkah selanjutnya yang dilakukan peneliti yaitu melakukan uji efek size, namun sebelum melangkah kepada uji tersebut data dianalisis dahulu melalui uji normalitas, homogenitas, liniearitas serta anacova.
Langkah pertama yang akan dilakukan peneliti setelah data terkumpul yaitu melakukan perhitungan normalitas, pada perhitungan ini terdapat 4 aspek yaitu pretest Inquiry, Postest Inquiry, Pretest Problem Solving dan Postest Problem Solving. Setelah uji normalitas diketahui dilanjutkan pada langkah kedua dengan melakukan uji homogenitas test. Tahap perhitungan ini melibatkan 2 aspek yaitu nilai/skor pretest baik di model Inquiry maupun di model Problem Solving dengan nilai/skor posttest di model Inquiry dan di model Problem Solving.

Pada langkah ketiga dilakukan uji liniearitas dengan melakukan perhitungan pada data posttest dengan data pretest. Terakhir pada langkah uji ANACOVA setelah ketiga syarat tersebut dipenuhi yaitu data terdistribusi normal, homogen dan linear, peneliti melakukan uji ANACOVA dengan menjadikan nilai postest sebagai variabel dependen dan nilai pretest digunakan sebagai nilai independent.

\section{HASIL DAN PEMBAHASAN}

Untuk memperoleh hasil penelitian, peneliti mengumpulkan beberapa sampel yang terdiri dari 10 jurnal Inquiry dan 11 jurnal Problem Solving. Berikut presentase skor pretest dan posttest yang telah peneliti rangkum dari kumpulan-kumpulan jurnal yang dianalisis

Tabel 1. Kumulatif nilai pretest dan posttest Inquiry Learning terhadap HOTs dan Miskonsepsi

\begin{tabular}{cccc}
\hline Kode & Pretest & Posttest & Peningkatan \\
\hline I-01 & 32,53 & 67,56 & 35,03 \\
I-02 & 43,13 & 72,66 & 29,53 \\
I-03 & 36,36 & 75,63 & 39,27 \\
I-04 & 39,38 & 57,55 & 18,17 \\
I-05 & 34,9 & 60,8 & 25,9 \\
I-06 & 33,5 & 71,7 & 38,2 \\
I-07 & 36,69 & 75,64 & 38,95 \\
I-08 & 33,23 & 56,2 & 22,97 \\
I-09 & 47,8 & 65,79 & 17,99 \\
I-10 & 34,39 & 62,82 & 28,43 \\
\hline Rata-rata & 37,191 & 66,635 & 29,444 \\
\hline
\end{tabular}

Berdasarkan hasil pada tabel 1 kumulatif nilai pretest dan posttest Inquiry Learning diperoleh rata-rata pretest sebesar 37,191 dan rata-rata posttest sebesar 66,635 . Sedangkan rata-rata peningkatan yang diperoleh dari skor rata-rata posttest - pretest sebesar 29,444. 
Tabel 2. Kumulatif nilai pretest dan posttest

Problem Solving terhadap HOTs dan Miskonsepsi

\begin{tabular}{cccc}
\hline Kode & Pretest & Posttest & Peningkatan \\
\hline PS-01 & 35,43 & 72,7 & 37,27 \\
PS-02 & 21,46 & 87,4 & 65,94 \\
PS-03 & 37,4 & 67,5 & 30,1 \\
PS-04 & 32,32 & 69,7 & 37,38 \\
PS-05 & 47,31 & 72,27 & 24,96 \\
PS-06 & 36,66 & 80,4 & 43,74 \\
PS-07 & 48,28 & 68,9 & 20,62 \\
PS-08 & 38,6 & 70,18 & 31,58 \\
PS-09 & 39,36 & 76,68 & 37,32 \\
PS-10 & 37,2 & 72,9 & 35,7 \\
PS-11 & 38,6 & 75,16 & 36,56 \\
\hline Rata-rata & 37,51091 & 73,98091 & 36,47 \\
\hline
\end{tabular}

Berdasarkan hasil pada tabel 2 kumulatif nilai pretest dan posttest Problem Solving diperoleh rata-rata pretest sebesar 37,510 dan rata-rata posttest sebesar 73,980 . Sedangkan rata-rata peningkatan yang diperoleh dari skor rata-rata posttest - pretest sebesar 36,47.

Selanjutnya peneliti mengkomparasi nilai rata-rata pretest dan posttest Inquiry Learning dan Problem Solving yang dirangkum pada gambar 2 dan tabel 3 sebagai berikut:

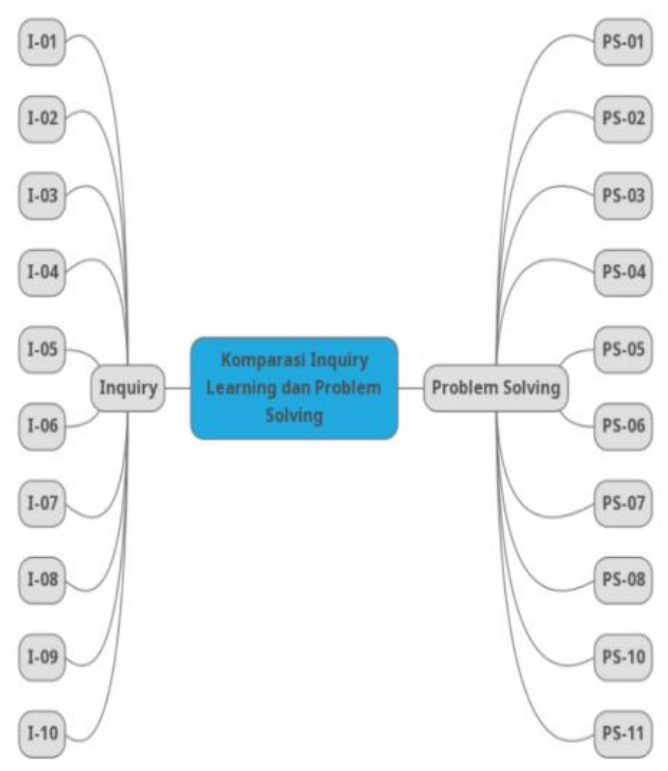

Gambar 2. Peta Konsep Analisis

Tabel 3. Komparasi Inquiry Learning dan Problem Solving

\begin{tabular}{cccc}
\hline Kode & Inquiry & $\begin{array}{c}\text { Problem } \\
\text { Solving }\end{array}$ & Selisih \\
\hline Pretest & 37,191 & 37,510 & 0,319 \\
Posttest & 66,635 & 73,980 & 7,345 \\
\hline
\end{tabular}

Tabel 3 menjelaskan bahwa pretest komparasi Inquiry dan Problem Solving memiliki selisih sebesar 0,319 , yang berarti kedua model tersebut sebelum diberikan treatment memiliki rata-rata yang hampir sama. Sedangkan Postest komparasi model Inquiry dan Problem Solving memiliki selisih sebesar 7,345 yang berarti kedua model tersebut jika dikomparasi memiliki pengaruh terhadap HOTs dan Reduksi Miskonsepsi pada pembelajaran Fisika.

Selanjutnya sebelum melakukan uji anacova, peneliti melakukan uji normalitas dan homogenitas serta uji liniearitas. Untuk uji normalitas peneliti menggunakan uji one sample komogorov smirnov test yang ditunjukan pada tabel 4. Hasil dari pengujian normalitas dikatakan memenuhi syarat apabila nilai sig $>0.05$. berikut hasil perhitungan normalitas.

Tabel 4. Uji Normalitas

\begin{tabular}{|c|c|c|c|c|c|}
\hline & & Pre In & Post In & Pre PS & Post PS \\
\hline $\mathrm{N}$ & & 10 & 10 & 11 & 11 \\
\hline Normal & Mean & 37.19 & 66.63 & 37.51 & 73.98 \\
\hline $\begin{array}{l}\text { Parameters } \\
a, b\end{array}$ & $\begin{array}{l}\text { Std. } \\
\text { Devia } \\
\text { tion }\end{array}$ & 4.91 & 7.192 & 7.12 & 5.79 \\
\hline $\begin{array}{l}\text { Most } \\
\text { Extreme }\end{array}$ & $\begin{array}{l}\text { Absol } \\
\text { ute }\end{array}$ & .241 & .159 & .216 & .210 \\
\hline Differences & $\begin{array}{l}\text { Positi } \\
\text { ve }\end{array}$ & .241 & .105 & .216 & .210 \\
\hline & $\begin{array}{l}\text { Negat } \\
\text { ive }\end{array}$ & -.172 & -.159 & -.203 & -.132 \\
\hline Test Statistic & & .241 & .159 & .216 & .210 \\
\hline $\begin{array}{l}\text { Asymp. Sig. ( } \\
\text { tailed) }\end{array}$ & & $.105^{c}$ & $.200^{c, d}$ & $.161^{c}$ & $.189^{c}$ \\
\hline $\begin{array}{l}\text { a. Test distrib } \\
\text { b. Calculated } \\
\text { c. Lilliefors Si } \\
\text { d. This is a lo }\end{array}$ & $\begin{array}{l}\text { ution is } \\
\text { from d } \\
\text { gnificar } \\
\text { wer bo }\end{array}$ & ormal. & n. & & \\
\hline
\end{tabular}

Berdasarkan hasil perhitungan diatas diperoleh nilai signifikasi pretest Inquiri pada sebesar 0,105 yang menandakan bahwa nilai $0,105>0,05$ dikatakan berdistribusi normal. Nilai signifikasi posttest Inquiry sebesar 0,2 berarti 0,2 > 0,05 diartikan berdistribusi normal. Kemudian nilai signifikasi pretest Problem Solving sebesar $0,161>0,05$ diartikan berdistribusi normal. Terakhir pada nilai signifikasi postetst Problem Solving sebesar $0,189>0,05$ bisa dikatakan juga berdistribusi normal.

setelah diuji normalitas datanya, selanjutnaya dilakukan uji nilai homogenitas dari data tersebut. Berikut tabel 5 dan 6 hasil perhitungan homogenitas pretest dan postest. 
Tabel 5. Homogenitas Pretest

\begin{tabular}{|lc|c|c|c|c}
\hline & & $\begin{array}{c}\text { Levene } \\
\text { Statistic }\end{array}$ & df1 & df2 & Sig. \\
\hline Pretest & $\begin{array}{l}\text { Based on } \\
\text { Mean }\end{array}$ & .143 & 1 & 19 & .709 \\
$\begin{array}{l}\text { Based on } \\
\text { Median }\end{array}$ & .234 & 1 & 19 & .634 \\
$\begin{array}{l}\text { Based on } \\
\text { Median and } \\
\text { with adjusted } \\
\text { df }\end{array}$ & .234 & 1 & 16. & .635 \\
$\begin{array}{l}\text { Based on } \\
\text { trimmed } \\
\text { mean }\end{array}$ & .208 & 1 & 19 & .654 \\
\hline
\end{tabular}

Tabel 6. Homogenitas Postest

\begin{tabular}{llr|r|r|r}
\hline & & $\begin{array}{c}\text { Levene } \\
\text { Statistic }\end{array}$ & df1 & df2 & Sig. \\
\hline $\begin{array}{l}\text { Postt } \\
\text { est }\end{array}$ & Based on Mean & 1.201 & 1 & 19 & .287 \\
\cline { 2 - 6 } & $\begin{array}{l}\text { Based on } \\
\text { Median }\end{array}$ & 1.409 & 1 & 19 & .250 \\
\cline { 2 - 6 } & $\begin{array}{l}\text { Based on } \\
\begin{array}{l}\text { Median and } \\
\text { with adjusted df }\end{array}\end{array}$ & 1.409 & 1 & 18. & .250 \\
& $\begin{array}{l}\text { Based on } \\
\text { trimmed mean }\end{array}$ & 1.292 & 1 & 19 & .270 \\
\hline
\end{tabular}

Tabel 5 menjelaskan nilai homogenitas pada pretest kedua model tersebut diperoleh nilai signifikasi 0,709 yang dikonsultasikan kesyarat dikatakan homogen apabila nilainya lebih besar dari 0,05 . Pada hasil tabel 5 nilai signifikasi $0,709>0.05$ sehingga dapat disimpulkan kedua model tersebut pada hasil pretest disebut homogen. Sedangkan pada tabel 6 menjelaskan nilai signifikasi homogenitas pada postest kedua model tersebut sebesar 0,287 yang berarti 0,287 $>0,05$ dan disimpulkan hasil signifikasi posttest kedua model tersebut juga homogen.

Terakhir sebelum melakukan uji ANACOVA syarat yang harus lakukan yaitu menguji liniearitasnya. Berikut hasil perhitungan pada tabel 7 uji liniearitasnya.

Tabel 7. Uji Liniearitas

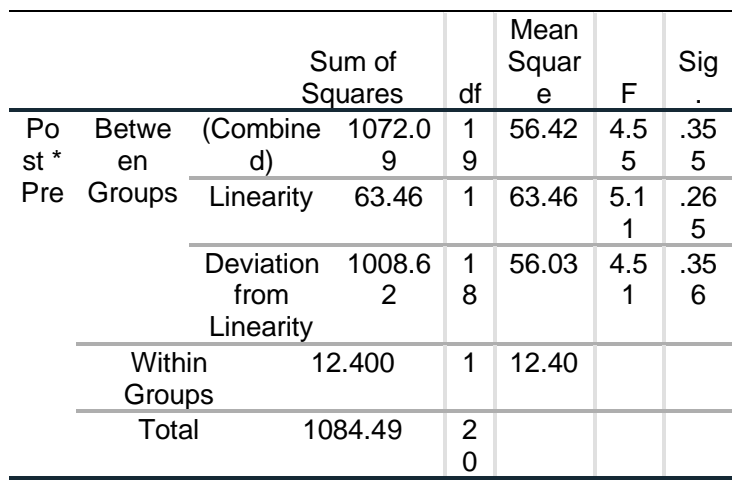

Hasil dari perhitungan uji liniearitas diperoleh hasil yaitu nilai signifikasi 0,356 yang kemudian dibandingkan dengan syarat dikatakan liniear apabila melebihi 0,05. Dari perhitungan tersebut terlihat jelas bahwa 0,356 $>0,05$ sehingga disimpulkan pengujian tersebut bersifat linier. Setelah ketiga syarat tadi sudah dilakukan : 1) Normalitas, 2) Homogenitas dan 3) Linieritas. Peneliti baru bisa melakukan uji ANACOVA guna menjawab permasalahan yang dihadapi. Hasil perhitungan uji ANACOVA yang telah dilakukan oleh peneliti berikut hasil ringkasannya.

Tabel 8. Hasil Uji ANACOVA

Tests of Between-Subjects Effects

\begin{tabular}{|c|c|c|c|c|c|}
\hline \multicolumn{6}{|c|}{$\begin{aligned} \text { Tests of Between-Subjects Effects } \\
\end{aligned}$} \\
\hline \multicolumn{6}{|c|}{ Dependent Variable: Posttest } \\
\hline Source & $\begin{array}{l}\text { Type III } \\
\text { Sum of } \\
\text { Squares }\end{array}$ & df & $\begin{array}{l}\text { Mean } \\
\text { Square }\end{array}$ & $\mathrm{F}$ & Sig. \\
\hline $\begin{array}{c}\text { Corrected } \\
\text { Model }\end{array}$ & $353.670^{\mathrm{a}}$ & 2 & 176.83 & 4.355 & .029 \\
\hline Intercept & 3410.36 & 1 & 3410.36 & 83.99 & .000 \\
\hline pretest & 71.01 & 1 & 71.01 & 1.749 & .203 \\
\hline kode & 290.20 & 1 & 290.20 & 7.148 & .015 \\
\hline Error & 730.82 & 18 & 40.60 & & \\
\hline Total & 105408.98 & 21 & & & \\
\hline $\begin{array}{c}\text { Corrected } \\
\text { Total }\end{array}$ & 1084.49 & 20 & & & \\
\hline
\end{tabular}

Hasil pada Tabel 8 tertera bahwa nilai

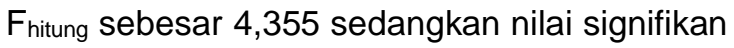
sebesar 0,029 dan nilai $F_{\text {tabel }}$ yang dicari pada tabel distribusi $F$ dengan probabilita sebesar 0,05 diperoleh sebesar 3,55. Nilai $F_{\text {tabel }}$ diperoleh dengan cara memasukan jumlah variabel sebesar 21 jurnal dengan rincian jurnal Inquiri Learning 10 jurnal dan Problem Solving 11 Jurnal. Kemudian jumlah jurnal tersebut dimasukan dalam persamaan $\mathrm{df}=\mathrm{n}-\mathrm{k}$, sehingga diperoleh $F_{\text {tabel }}=3,55$. Hasil analisis pada Tabel 2 menjelaskan bahwa $F_{\text {hitung }}>F_{\text {tabel }}$ yaitu 4,355 $>3,55$, dan nilai probabilita $0,029<0,05$ yang berarti memiliki makna bahwa Inquiry Learning dan Problem Solving memiliki pengaruh dalam peningkatan HOTs dan mereduksi miskonsepsi pelajaran fisika.

Selain hasil kuantitatif yang diperoleh peneliti, peneliti memperoleh temuan-temuan yang diperoleh dari jurnal-jurnal yang dijadikan sumber acuan data. Temuan yang diperoleh peneliti pada jurnal inkuiri yaitu pertama, kelas yang medapatkan perlakuan dengan menggunakan Inquiry Learning cenderung 
siswa yang belajar menjadi aktif dalam belajar hal tersebut karena karakteristik dari Inquiry Learning menekankan pada aspek kognitif, afektif dan psikomotorik yang berjalan secara balance (Handriani et al, 2017; Amijaya et al, 2018). Dengan berjalan secara seimbang ketiga aspek tersebut tentunya pembelajran yang dijalankan menjadi lebih bermakna bagi siswa, selain itu dengan Inquiry Learning keterampilan siswa dalam berpikir tingkat tinggi atau HOTs juga semakin terasah (Sadia \& Gunandi; 2019) .

Kedua, Inquiry Learning memberikan korelasi postif terkait HOTs denganhasil belajar, artinya jika HOTs siswa meningkat sudah bisa dipastikan bahwa hasil belajar siswa meningkat dan KKM yang diharapkan akan tercapai (Amijaya et al, 2018).

\section{Ketiga, Inquiry Learning yang menerapkan keterampilan berpikir kritis menurut (Ratnaningdyah \& Sugiarti, 2018; Maryam et al, 2020) tentunya mampu mereduksi miskonsepsi yang diterima siswa dalam belajar karena dalam hal tersebut indikator berpikir kritis evaluation, explanation dan self-regulation memberikan kesempatan kepada siswa untuk memberikan argumen dan mengevaluasi argumen dari siswa lain terkait informasi yang diterima.}

Sedangkan, pada jurnal-jurnal problem solving peneliti menemukan beberapa temuan yang mampu memperkuat penelitian yang dilakukan yaitu: pertama, problem solving mampu meningkatkan keterampilan HOTs karena pada problem solving siswa dilatih untuk terbiasa dalam memecahkan masalah yang berkaitan terhadap kehidupan nyata yang mereka hadapi sesuai dengan materi yang diajarkan, selain melatih terbiasanya memecahkan suatu masalah problem solving juga mampu mengembangkan wawasan serta daya pikir untuk terus berkembang (Daryanti et al, 2019).

Kedua, dengan memanfatkan media seperti modul, aplikasi Phet atau media interaktif mampu mereduksi miskonsepsi serta meningkatkan HOTs siswa (Septian \& Kurniawan, 2019), selain pemanfaat media yang mampu meningkatkan HOTs dan mereduksi miskonsepsi, dengan strategi demontrasi dan eksperimen mampu meningkatkan keterampilan HOTs dan reduksi miskonsepsi (Nurhasanah \& Oktaavianty).

\section{PENUTUP}

Berdasarkan data yang telah diperoleh peneliti menyimpulkan bahwa 1) komparasi Inquiry Learning dan Problem solving mampu meningkatkan HOTs siswa dalam belajar dan mampu mereduksi miskonsepsi fisika sesuai hasil data statistik yaitu $F_{\text {hitung }}>F_{\text {tabel }}$ yaitu 4,355 $>3,55$, dan nilai probabilita $0,029<0,05$. 2) hasil temuan yang diperoleh peneliti melalui jurnaljurnal yang berkaitan dengan tema penelitian menunjukan bahwa masing-masing model terbukti memberikan pengaruh positif terhadap HOTs maupun reduksi miskonsepsi fisika.

\section{REFERENSI}

Amijaya, L. S., Ramdani, A., \& Merta, I. W. (2018). Pengaruh model pembelajaran inkuiri terbimbing terhadap hasil belajar dan kemampuan berpikir kritis peserta didik. Jurnal Pijar Mipa, 13(2), 94-99.

Anugraheni, I. (2018). Meta Analisis Model Pembelajaran Problem Based Learning dalam Meningkatkan Keterampilan Berpikir Kritis di Sekolah Dasar [A Metaanalysis of Problem-Based Learning Models in Increasing Critical Thinking Skills in Elementary Schools]. Polyglot: Jurnal Ilmiah, 14(1), 9 - 18.

Ariyani, I. D. (2019, May). Peran Tenaga Pendidik Dalam Memberikan Pembelajaran Yang Bermakna Dengan Menggunakan Pendekatan Etnomatematika. In Prosiding Seminar Nasional Pendidikan FKIP (Vol. 2, No. 1, pp. 77-84).

Baharuddin, I. (2020). Pembelajaran bermakna berbasis daring di tengah pandemi covid19. Kelola: Journal of Islamic Education Management, 5(2), ,79-88.

Daryanti, S., Sakti, I., \& Hamdani, D. (2019). Pengaruh pembelajaran model problem solving berorientasi higher order thinking skills terhadap hasil belajar fisika dan kemampuan pemecahan masalah. Jurnal Kumparan Fisika, 2(2), 65-72. 
Halim, H. (2018). Bimbingan Individu Dan Diskusi Sesama Guru Dapat Meningkatkan Kemampuan Guru Dalam Membuat Pembelajaran Yang Bermakna Di SDN 13 Padang Gelanggang Tahun Pelajaran 2012/2013. Jurnal Pendidikan Tambusai, 2(3),1928-1936.

Handayani, M. W., Swistoro, E., \& Risdianto, E. (2018). Pengaruh Model Pembelajaran Problem Solving Fisika terhadap Kemampuan Penguasaan Konsep dan Kemampuan Pemecahan Masalah Siswa Kelas X MIPA SMAN 4 Kota Bengkulu. Jurnal Kumparan Fisika, 1(3), 36-44.

Handriani, L. S., Harjono, A., \& Doyan, A. (2017). Pengaruh model pembelajaran inkuiri terstruktur dengan pendekatan saintifik terhadap kemampuan berpikir kritis dan hasil belajar fisika siswa. Jurnal Pendidikan Fisika dan Teknologi, 1(3), 210-220.

Jundu, R., Tuwa, P., \& Seliman, R. (2020). Hasil Belajar IPA Siswa SD di Daerah Tertinggal dengan Penerapan Model Pembelajaran Inkuiri Terbimbing Scholaria:Jurnal Pendidikan Dan Kebudayaan, 10(2), 103-111.

Maryam., Kusmiyati., Merta, I W \& Artayasa. (2020). Pengaruh Model pembelajran Inkuiri Terhadap Keterampilan Berpikir Kritis Siswa. Jurnal Pijar Mipa, 15(3), 206-213

Muamanah, H., \& ., Suydi. (2020). Pelaksanaan Teori Belajar Bermakna David Ausubel Dalam Pembelajaran Pendidikan Agama Islam. Belajea: Jurnal Pendidikan Islam, 5(1), 161-180.

Nurfitria, D., \& Hertanti, E. (2020). The Efect Inquiry Learning Model With Pictorial Riddle Teachnique Digital Based on Students Creative Thingking Ability Towards Temperature and Heat Concept. EDUSAINS, 12(2), 276-282.

Nurhamidah, D., Masykuri, M., \& Dwiastuti, S. (2019). Biology Module based on Cooperative Problem-based Learning (CPBL) to Enhance Students' Problem Solving Skills at Madrasah Aliyah Negeri. EDUSAINS, 11(1), 147-155.

Nurhasanah, N., \& Oktavianty, E. Integrasi Remediasi Miskonsepsi dalam Pembelajaran Model Problem Solving Materi Suhu dan Kalor di Man (Doctoral dissertation, Tanjungpura University).
Pane, A., \& Darwis Dasopang, M. (2017) Belajar dab Pembelajaran. FITRAH: Jurnal Kajian IImu-ilmu Keislaman, 3(2)

Ratnaningdyah, D., \& Sugiarti, S. (2018). Mereduksi Jumlah Mahasiswa Yang Mengalami Miskonsepsi Fisika Pada Materi Listrik Dengan Model Pembelajaran Inkuiri. Jurnal Inovasi dan Pembelajaran Fisika, 5(2), 175-180.

Sadia, I. W., \& Gunadi, I. G. A. (2019). Pengaruh model pembelajaran inkuiri terbimbing terhadap keterampilan berpikir kritis siswa pada pembelajaran fisika kelas X IPA SMA Negeri. Jurnal Pendidikan Fisika Undiksha, 9(1), 63-74.

Septian, D., \& Kurniawan, G. E. (2019). Pengembangan Modul Fisika Berbasis Problem Solving Untuk Meningkatkan High Order Thinking Skill Pada Materi Fluida Statis Kelas XI MAN 2 Kuningan. Jurnal Pendidikan Fisika dan Sains (JPFS), 2(1), 30-36.

Setyowati, R., \& Fimansyah, W. (2018). Upaya peningkatan citra pembelajaran IPS bermakna di Indonesia. Jurnal PIPSI (Jurnal Pendidikan IPS Indonesia), 3(1), 14-17.

Setyowati, N., \& Mawardi, M. (2018). Sinergi Project Based Learning dan Pembelajaran Bermakna untuk Meningkatkan Hasil Belajar Matematika. Scholaria: Jurnal Pendidikan Dan Kebudayaan, 8(3), 253263.

Sholeh, M., Jannah, R., Mahmudah, M., \& Khairunnisa, K. (2021). Pengembangan Model Pembelajaran Efektif Dan Bermakna Di MI Perwanida Blitar. Muallimuna: Jurnal Madrasah Ibtidaiyah, 6(2),16-31.

Sutikno, M. S. (2021). Strategi Pembelajaran. Indramayu: Penerbit Adab. 